Elsevier required licence: (C) <2019>. This manuscript version is made available under the CC-BY-NC-ND 4.0 license http://creativecommons.org/ licenses/by-nc-nd/4.0/. The definitive publisher version is available online at [insert DOI] 


\title{
Effect of additional food waste slurry generated by mesophilic acidogenic fermentation on nutrient removal and sludge properties during wastewater treatment
}

\author{
Jialing Tang ${ }^{\mathrm{a}, \mathrm{b}}$, Yunhui $\mathrm{Pu}^{\mathrm{a}}$, Xiaochang C. Wang, ${ }^{\mathrm{b}, \mathrm{c}, \mathrm{d}, *}$, Yisong Hu${ }^{\mathrm{b}, \mathrm{c}}$, Jin Huang ${ }^{\mathrm{a}}$, Huu Hao Ngo ${ }^{\mathrm{e}}$, \\ Shengwang Pan ${ }^{\mathrm{a}}$, Yuyou Li ${ }^{\mathrm{f}}$, Nengmin $\mathrm{Zhu}^{\mathrm{g}}$ \\ ${ }^{a}$ School of Architecture and Civil Engineering, Chengdu University, Chengdu 610106, China \\ ${ }^{\mathrm{b}}$ Key Lab of Northwest Water Resource, Environment and Ecology, MOE, Xi'an University of Architecture and Technology, Xi'an 710055, China \\ ${ }^{\mathrm{c}}$ International Science \& Technology Cooperation Center for Urban Alternative Water Resources Development, Xi'an 710055, China \\ ${ }^{\mathrm{d}}$ Engineering Technology Research Center for Wastewater Treatment and Reuse, Shaanxi Province, China \\ ${ }^{\mathrm{e}}$ Centre for Technology in Water and Wastewater, School of Civil and Environmental Engineering, University of Technology Sydney, Sydney, NSW 2007, Australia \\ ${ }^{\mathrm{f}}$ Department of Civil and Environmental Engineering, Tohoku University, Sendai 9808579, Japan \\ ${ }^{\mathrm{g}}$ Biogas Scientific Research Institute of the Ministry of Agriculture, Chengdu 610041, China
}

A R T I C L E I N F O

\section{Keywords:}

Fermentation slurry from food waste

$\mathrm{C} / \mathrm{N}$ ratio

Nutrient removal

Carbon source

Microbial community

\begin{abstract}
A B S T R A C T
Fermentation slurry from food waste (FSFW) generated by acidogenic fermentation at mesophilic temperature was utilized to improve the nutrients removal from wastewater. Organic acids (such as lactate and volatile fatty acids) in the FSFW behaved as readily biodegradable carbon sources, while the particulate and macromolecular organics acted as slowly biodegradable carbon sources during denitrification processes. The FSFW dosage significantly influenced the nitrogen removal performance, and a $\mathrm{C} / \mathrm{N}$ ratio (in terms of chemical oxygen demand to nitrogen ratio) of 8 could achieve complete denitrification in the batch tests. In a sequencing batch reactor (SBR) using FSFW for long-term wastewater treatment, extracellular polymeric substances (EPS) gradually accumulated, sludge particle size significantly increased, and microbial communities were selectively enriched, which contributed to promoting the nitrogen $(>80 \%)$ and phosphate $(90.1 \%)$ removal efficiencies. Overall, the FSFW produced by acidogenic fermentation under mesophilic temperature served as an excellent intermediary between FW valorization and wastewater treatment.
\end{abstract} China.

E-mail address: xcwang@xauat.edu.cn (X.C. Wang). 


\section{Introduction}

Wastewater and solid wastes have become two major barriers in the development of cities, as they not only deteriorate the environment, but also threaten human health (Braguglia et al., 2018; Tang et al., 2019; Zhou et al., 2018). Biological wastewater treatment processes can effectively remove pollutants and improve the water quality to some extent, but the nitrogen and phosphate removal efficiencies are unsatisfactory owing to the insufficiency of organics in the raw wastewater. Therefore, researchers still aim to develop effective and feasible approaches to further reducing the nutrient contents and meeting the requirements of the increasingly stringent effluent standards (Cao et al., 2019a; Tang et al., 2018). On the other hand, the production of large amounts of solid waste, particularly organic solid wastes from production and daily life, also directly diminish the environmental quality. Food waste (FW), a typical organic solid waste, will severely contaminate the air, water, and soil during collection, transportation, and storage without proper treatment, as it is easily degradable and produced in large quantities (Braguglia et al., 2018; Capson-Tojo et al., 2016; Zhou et al., 2018). The traditional FW disposal methods, such as feeding to animals, composting to produce fertilizer, landfilling, and incineration, have become insufficient due to the shortage of land and incomplete removal of contaminants (Kwan et al., 2018; Mehariya et al., 2018; Zhang et al., 2014). Moreover, the easy degradability of the organic matter in the FW would lower the hydrolysis rate of substrates and restrict the methanogenesis processes in the anaerobic digestion systems (Jiang et al., 2018; Kim et al., 2019). Thus, an applicable and effective wastewater treatment and solid waste disposal pathway should be developed to simultaneously protect the environment and recycle waste.

Supplying additional carbon sources is a feasible method of improving insufficient nutrients removal efficiencies. However, chemical carbon sources, such as acetate, methanol, and glucose would increase the operation cost and pose a risk to transportation and human health, which are not conducive to practical operation (Cao et al., 2019a). Recently, many researchers have attempted to use fermentation products from organic solid waste (such as food waste and excess sludge) or wastewater as external carbon sources to promote the removal of nutrients from wastewater, which would not only recycle organic wastes, but also reduces the operational costs of wastewater treatment (Cao et al., 2019a; Kim et al., 2017; Tang et al., 2019; Zhang et al., 2016a). During fermentation, organic solid wastes are hydrolyzed and then transformed into organic acids by acidogens to produce readily biodegradable carbon sources. Many researchers have effectively used volatile fatty acids (VFAs) generated from activated sludge to promote the nitrogen and phosphate removal efficiencies (Cao et al., 2019a; Liu et al., 2018), and alkaline fermentation is an effective method of improving the VFA yields from activated sludge, which could simultaneously reduce the amount of sludge, recover carbon source and enhance nutrient removal efficiencies (Liu et al., 2018). However, the refractory dissolved organic matter (rDOM) in fermented products is resistant to microbial degradation, and could deteriorate the effluent quality (Cao et al., 2019a). Most of the organics (carbohydrates, proteins, and lipids) in FW can be rapidly transformed into easily-biodegradable organic acids (VFAs and lactic acid (LA)) under low-pH conditions, and can be completely degraded by microorganisms in wastewater treatment systems without threatening the effluent quality (Tang et al., 2019; Zhang et al., 2016b). Thus, using FW to produce high-quality carbon sources for promoting nitrogen removal is a feasible solution for solid waste disposal and nutrient removal from wastewater.

The nutrient removal performance is influenced by the organic components of fermentation products. Soluble organics (organic acids and carbohydrates) in the fermentation liquid of food waste (FLFW) are easily biodegradable carbon sources that have significantly increased microbial diversity, improved the bacterial metabolic capacity for carbon, and promoted the nitrogen removal efficiency in both lab- and pilot-scale wastewater treatment systems (Zhang et al., 2016b; Tang et al., 2018). However, the particulate organic matter in fermentation slurry must be hydrolyzed into soluble organics before use by denitrifiers (Drewnowski and Makinia, 2014; Tang et al., 2019). Additionally, particulate organics are favorable for enlarging sludge flocs and improving their settleability. In a recent study, simultaneous nitrification and denitrification (SND) and anoxic denitrifying phosphate accumulation processes using thermophilic fermentation slurry have been conducted in lab-scale sequencing batch reactors (SBRs), and were demonstrated to be related to the existence of particulate organics in the FSFW (Tang et al., 2019). The aforementioned studies indicate that both soluble and particulate organics in the fermentation products could be effectively utilized as external carbon sources for nutrient removal. However, the organics in the FSFW generated at mesophilic temperature were different from those produced at thermopilic temperatures, which might result in distinct microbial communities and nutrient removal performance. Additionally, the effects of $\mathrm{C} / \mathrm{N}$ ratios on pollutants removal performance using fermentation slurry generated under mesophilic temperature as carbon source has not yet been explored, the functions of soluble and particulate organics in the FSFW in nitrogen removal processes are not understood, and the effect of FSFW on sludge properties and microbial communities has not yet been clarified, which should be further investigated.

Therefore, in this study, the nutrient removal performance and sludge properties using the FSFW produced under a mesophilic temperature were investigated to further optimize the combined solution for solid waste disposal and wastewater treatment.

\section{Materials and methods}

\subsection{Food waste substrate}

Food wastes (FW), mainly composed of rice, vegetables and meat, was collected from the student canteen in a university campus in Chengdu, China. The FW pretreated procedures were the same to those described in our previous study (Tang et al., 2016). Firstly, the fresh FW was crushed using an electrical blender after manually sorting out animal bones, napkin tissues and other nonbiodegradable substances. Then the resulting slurry was sieved $(1 \mathrm{~mm})$ and stored in the refrigerator $\left(4^{\circ} \mathrm{C}\right)$ until further use. Before the fermentation, total solids (TS) content of the fresh FW slurry was adjusted with tap water to approximately $8 \pm 0.5 \%$. The characteristics of food waste slurry were shown in Table 1.

\subsection{Preparation of FSFW}

A continuous stirring tank reactor (CSTR) with a working volume of $5 \mathrm{~L}$ was used to produce the FSFW. Fresh FW slurry (prepared in Section 2.1) was added to the CSTR and fermented at $37^{\circ} \mathrm{C}$ using a water bath

Table 1

Characteristics of the food waste substrate and FSFW.

\begin{tabular}{llll}
\hline Parameter & Unit & Fresh FW & FSFW \\
\hline $\mathrm{pH}$ & - & $4.9 \pm 0.2$ & $3.4 \pm 0.2$ \\
$\mathrm{TS}$ & \% of wet weight & $8.0 \pm 0.5$ & $7.7 \pm 0.2$ \\
$\mathrm{VS} / \mathrm{TS}$ & $\%$ & $92.4 \pm 5.6$ & $90.1 \pm 3.3$ \\
$\mathrm{COD}$ & $\mathrm{g} / \mathrm{L}$ & $88.6 \pm 7.6$ & $82.0 \pm 12.7$ \\
$\mathrm{SCOD}$ & $\mathrm{g} / \mathrm{L}$ & $28.8 \pm 2.3$ & $48.2 \pm 5.9$ \\
Carbohydrate & $\mathrm{g} / \mathrm{L}$ & $57.5 \pm 2.7$ & $8.2 \pm 2.5$ \\
Protein & $\mathrm{g} / \mathrm{L}$ & $12.1 \pm 1.6$ & $8.7 \pm 3.8$ \\
Lactic acid & $\mathrm{g} / \mathrm{L}$ & $2.9 \pm 0.7$ & $26.8 \pm 1.7$ \\
VFAs & $\mathrm{g} / \mathrm{L}$ & $0.7 \pm 0.3$ & $8.6 \pm 2.3$ \\
$\mathrm{NH}_{4}{ }^{+}-\mathrm{N}$ & $\mathrm{mg} / \mathrm{L}$ & $167.6 \pm 13.1$ & $319.1 \pm 48.1$ \\
$\mathrm{TN}$ & $\mathrm{g} / \mathrm{L}$ & $1.6 \pm 0.5$ & $1.8 \pm 0.4$ \\
$\mathrm{TP}$ & $\mathrm{g} / \mathrm{L}$ & $0.2 \pm 0.1$ & $0.3 \pm 0.1$ \\
\hline
\end{tabular}


to control the temperature. According to the previous study, a pH of 4 could relieve the feed-back inhibition caused by acid accumulation, improve the hydrolysis and acidification rate, and reduce the loss of organics (Tang et al., 2016). Thus, the $\mathrm{pH}$ value in the CSTR was adjusted to 4 using sodium hydroxide $(5 \mathrm{~mol} / \mathrm{L})$. One liter of the fermented slurry was drained from the fermenter daily and replaced with the same volume of fresh FW slurry (TS $=8 \%$ ) to maintain a solid retention time (SRT) of five days. The organic compounds in the fermented slurry, such as carbohydrates, proteins, lactic acid, and VFAs, were analyzed (Table 1).

\subsection{Denitrification properties of the FSFW under different $C / N$ ratios}

To investigate the denitrification properties of the FSFW, a series of nitrate uptake rate (NUR) tests were conducted following the methods described in the previous studies (Cao et al., 2019a; Sage et al., 2006; Tang et al., 2017; Zhang et al., 2016a). Firstly, the denitrification sludge was withdrawn from a lab-scale SBR which had a total nitrogen (TN) removal rate over $90 \%$ with FSFW as external carbon sources (Tang et al., 2019). Then the activated sludge was washed with pure water several times to remove the residual substrates. Thereafter, the washed sludge was transferred into five 2 L-flasks with a mixed liquor volatile suspended solid (MLVSS) of approximately $3 \mathrm{~g} / \mathrm{L}$. Oxygen in the mixed liquor was eliminated by flushing with nitrogen gas $\left(\mathrm{N}_{2}\right)$. Following this, sodium nitrate $\left(\mathrm{NaNO}_{3}\right)$ was added to each flask to generate a final $\mathrm{NO}_{3}{ }^{-}$-N content of approximately $50 \mathrm{mg} / \mathrm{L}$. Subsequently, different amount of FSFW was added to generate a series of $\mathrm{C} / \mathrm{N}$ ratios of around 2, 4, 6, 8 and 10. A control test was simultaneously conducted with $50 \mathrm{mg} / \mathrm{L}$ of $\mathrm{NO}_{3}{ }^{-}-\mathrm{N}$, but no additional carbon source was supplied. The flasks were then sealed and the liquor was mixed with stirrers. Periodically, $10 \mathrm{~mL}$ of the mixed liquor was sampled from each flask to analyze the $\mathrm{NO}_{3}{ }^{-}-\mathrm{N}$ and $\mathrm{NO}_{2}{ }^{-}-\mathrm{N}$. The specific denitrification rate (SDNR) was calculated based on the methods in the previous study (Sage et al., 2006).

\subsection{Functions of the organic matter in FSFW during denitrification}

To further elucidate the relationships between the utilization of organic compounds and denitrification, the soluble (filtrate using the $0.45-\mu \mathrm{m}$ filter) and solid (residual matter on the $0.45-\mu \mathrm{m}$ filter) fractions of the FSFW, and the FSFW were severally added into three flasks as sole carbon sources to conduct another series of NUR tests. The sludge pretreatment processes were the same as those described in Section 2.3. After the sludge was prepared, sodium nitrate $\left(\mathrm{NaNO}_{3}\right)$ was added to each flask to achieve a final $\mathrm{NO}_{3}{ }^{-}-\mathrm{N}$ concentration of approximately $50 \mathrm{mg} / \mathrm{L}$, and the soluble and solid fractions of the FSFW, and FSFW mixture were added to each flask to achieve a COD content of approximately $400 \mathrm{mg} / \mathrm{L}$. The mixed liquor of each flask was intermittently sampled to analyze the concentrations of soluble COD (SCOD), $\mathrm{NO}_{3}{ }^{-}-\mathrm{N}, \mathrm{NO}_{2}{ }^{-}-\mathrm{N}$, lactate, soluble carbohydrate, soluble protein, and VFAs. The SDNR was calculated following the methods described in previous studies (Sage et al., 2006; Tang et al., 2019). NUR tests were conducted three times in parallel, and the representative results were reported.

\subsection{Wastewater treatment using the FSFW for long-term operation}

To explore the effects of the FSFW on the performance of nitrogen removal processes and the characteristics of activated sludge, a stepfeeding sequencing batch reactor (SFSBR) with a working volume of $5 \mathrm{~L}$ were operated in the laboratory with the FSFW as external organic carbon sources. The schematics and operation sequences of the SFSBR were described in the Supplementary Information. The inoculated sludge was obtained from the anoxic tank of a pilot-scale membrane bioreactor described in our previous study (Tang et al., 2017). Before the experiment, the SFSBR had been continuously operated for two months to treat the domestic wastewater with low organics content (C/ $\mathrm{N}<6$ ), during which time the reactor exhibited a low nitrogen removal efficiency (20-30\%). The FSFW, ammonia and phosphate were added into the influent to adjust the COD (about $400 \mathrm{mg} / \mathrm{L}$ ), $\mathrm{NH}_{4}{ }^{+}-\mathrm{N}$ (around $50 \mathrm{mg} / \mathrm{L}$ ) and $\mathrm{PO}_{4}{ }^{3-}-\mathrm{P}$ (approximately $6 \mathrm{mg} / \mathrm{L}$ ), respectively. Hydrolytic retention time (HRT) of the SFSBR was $10 \mathrm{~h}$, and the sludge retention time (SRT) of the SFSBR was maintained at approximately 30 days by discharging the excess sludge every day. Mixed-liquid suspended solids (MLSS) fluctuated between 3 and $5 \mathrm{~g} / \mathrm{L}$, and the ratio of mixed-liquid volatile suspended solids (MLVSS) to MLSS was approximately $0.7-0.8$ during the operation.

\subsection{Analysis methods}

\subsubsection{Extraction and measurement of EPS}

Extracellular polymeric substances (EPS) in the activated sludge were analyzed. Both soluble EPS (SEPS) and bound EPS (BEPS) were extracted from activated sludge using a thermal treatment method $\mathrm{Hu}$ et al., 2013). Briefly, $25 \mathrm{~mL}$ of the mixed liquors were sampled from the SFSBR at the last aeration stage. The sludge samples were firstly centrifuged at $6000 \mathrm{rpm}$ and $4{ }^{\circ} \mathrm{C}$ for $10 \mathrm{~min}$ using a centrifuge (Model TGL$16 \mathrm{M}$, Shanghai, China). Then the supernatant was filtered through a $0.22 \mu \mathrm{m}$ filter to obtain the soluble organic fraction as SEPS. The residues were recovered and re-suspended to their original volume in a buffer solution, and then they were used for the extraction of BEPS by heating at $60^{\circ} \mathrm{C}$ for $30 \mathrm{~min}$, centrifuging at $10,000 \mathrm{rpm}$ and $4{ }^{\circ} \mathrm{C}$ for $20 \mathrm{~min}$, and filtering the supernatant through a $0.22 \mu \mathrm{m}$ filter. The contents of EPS samples were analyzed in terms of proteins and polysaccharides. Polysaccharides were detected using the anthrone method with glucose as a standard (Frølund et al., 1996), and proteins were quantified using a modified Lowry method using bovine serum albumin (BSA) as the standard reference (Lowry et al., 1951).

\subsubsection{Three-dimensional excitation-emission matrix fluorescence spectra (3D-EEM)}

To characterize the components in EPS, both SEPS and BEPS were analyzed using a FP-6500 spectroflurometer (Jasco Corporation, Japan). The emission spectra of the EEM were scanned with the excitation wavelength varied from 220 to $550 \mathrm{~nm}$ in $5 \mathrm{~nm}$ increment. Subsequently, the EEM spectra were assessed using Origin Pro 8.0 software (Origin Lab Corporation, USA) and elliptical shape contours were obtained.

\subsubsection{Particle size distribution (PSD) analysis}

PSD of the sludge samples in the SBR during the operation was measured using a laser granularity distribution analyzer (LS 230/SVM + , Beckman Coulter Corporation, USA), which had a detection range of $0.4-2000 \mu \mathrm{m}$ and showed a good accuracy and reproducibility. In this study, the typical PSD curves were reported.

\subsubsection{Microbial communities analysis}

To investigate the variations in microbial communities, activated sludge samples before (0 Day) and after (100 Day) adding the FSFW were sent to Sangong, Inc. (Shanghai, China) for DNA extraction and next-generation sequencing processes. The extracted DNA was amplified by polymerase chain reaction (PCR) using the primer 27F ( 5'-AGAGTTTGATCMTGGCTCAG-3') and 519R (5'-GWATTACCGCGGCKGCTG-3') for the V1-V3 region of the 16S rRNA genes (Tang et al., 2019; Luo et al., 2017). 16S rRNA genes amplicon sequencing was conducted using an Illumina MiSeq platform. The homologous or ambiguous sequences or those with a length shorter than $200 \mathrm{bp}$ were trimmed to obtain high-quality sequences with an average length larger than $500 \mathrm{bp}$ for the taxonomic classification. 

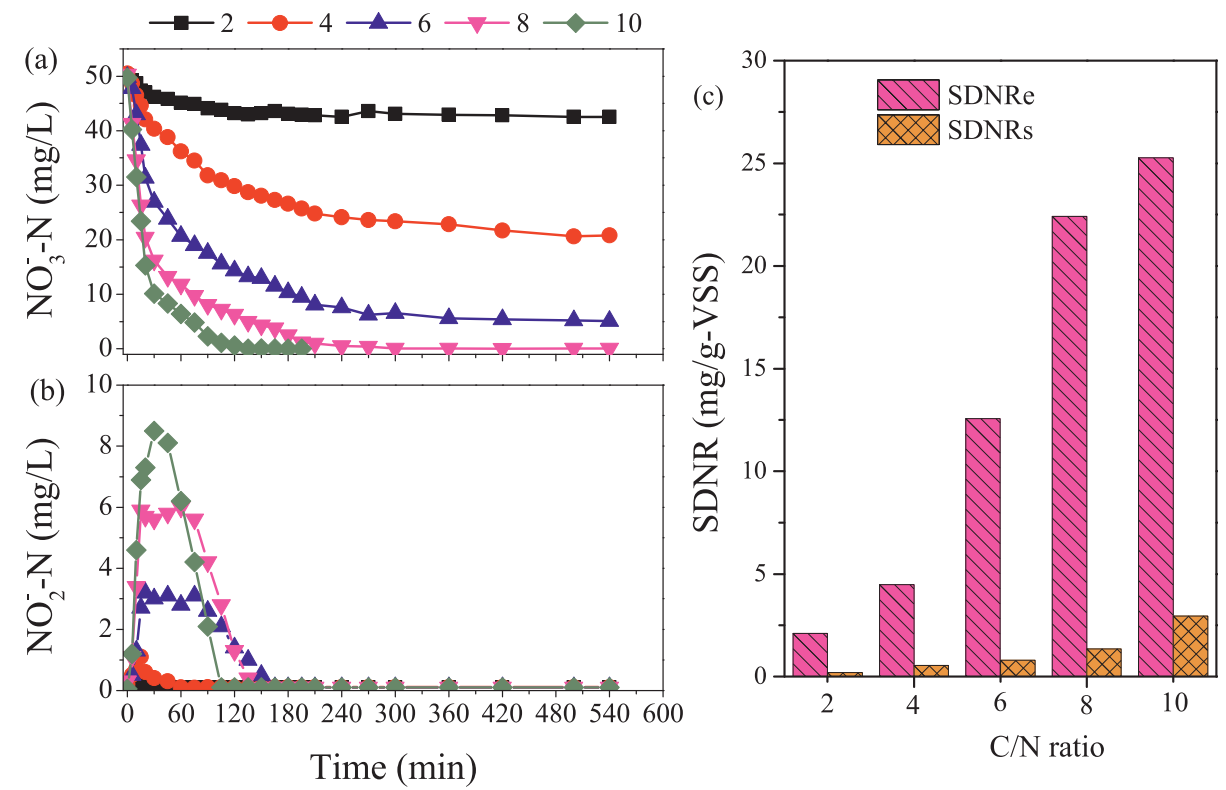

Fig. 1. Denitrification properties of the FSFW under different C/N ratios. (a) $\mathrm{NO}_{3}{ }^{-}-\mathrm{N}$ content, (b) $\mathrm{NO}_{2}{ }^{-}-\mathrm{N}$ content and (c) SDNR.

\subsection{Additional analytical methods}

The components in the fermented slurry was analyzed according to our previous study (Tang et al., 2016). Influent, effluent and mixed liquor were periodically sampled from the SFSBR, nitrogen compounds $\left(\mathrm{NH}_{4}{ }^{+}-\mathrm{N}, \mathrm{NO}_{3}{ }^{-}-\mathrm{N}, \mathrm{NO}_{2}{ }^{-}-\mathrm{N}\right.$ and total nitrogen (TN)), chemical oxygen demand (COD), $\mathrm{PO}_{4}{ }^{3-}-\mathrm{P}$, MLSS, MLVSS, and sludge volume index (SVI) were measured according to standard methods (APHA, 2012). Specific oxygen uptake rate (SOUR) of the activated sludge was measured according to Surmacz-Gorska (Surmacz-Gorska et al., 1996). Dewaterability, in terms of capillary suction time (CST) was analyzed using a capillary suction timer (294-50, OFI Testing Equipment, Inc., USA).

\section{Results and discussion}

\subsection{Characteristics of nutrient removal using the FSFW as carbon source}

\subsubsection{Denitrification properties of the FSFW at different $C / N$ ratios}

The denitrification properties at various $\mathrm{C} / \mathrm{N}$ ratios with FSFW as carbon source were first investigated (Fig. 1). In the reactor with a $\mathrm{C} / \mathrm{N}$ ratio of 2 (Fig. 1a), $\mathrm{NO}_{3}{ }^{-}-\mathrm{N}$ concentration in the reactor slightly decreased from 50.1 to $42.5 \mathrm{mg} / \mathrm{L}$, which was mainly due to the insufficient amount of organic matter for denitrification. The theoretical carbon demand for complete denitrification is $2.86 \mathrm{~g} \mathrm{COD} / \mathrm{g} \mathrm{NO}_{3}{ }^{-} \mathrm{N}$, and a higher $\mathrm{C} / \mathrm{N}$ ratio is required due to the metabolism by other bacteria (Cao et al., 2019b). Thus, a C/N ratio of 2 could not provide sufficient carbon source for denitrification and resulted in a high residual nitrate content. With the addition of more FSFW, the $\mathrm{NO}_{3}{ }^{-}-\mathrm{N}$ content of the mixed liquor decreased more rapidly. At a $\mathrm{C} / \mathrm{N}$ of 4 , the $\mathrm{NO}_{3}{ }^{-}$-N concentration continuously decreased from 50.5 to $24.8 \mathrm{mg} / \mathrm{L}$ during the initial $210 \mathrm{~min}$, and then slightly decreased to $20.8 \mathrm{mg} / \mathrm{L}$ at the end of the tests, exhibiting a two-stage nitrate reduction pattern that was mainly due to the properties of organic components of the FSFW. The micromolecular organics in the FSFW could be easily utilized by microorganisms, which results in a faster denitrification rate, while solid and macromolecular organics are firstly hydrolyzed into soluble organic matter before being utilized by denitrifying bacteria, resulting in a lower denitrification rate (Drewnowski and Makinia, 2014; Tang et al., 2019). By increasing the $\mathrm{C} / \mathrm{N}$ ratio to 6 , the $\mathrm{NO}_{3}{ }^{-}-\mathrm{N}$ concentration decreased from 49.8 to $23.9 \mathrm{mg} / \mathrm{L}$ within $45 \mathrm{~min}$, and then gradually decreased to $5.6 \mathrm{mg} / \mathrm{L}$ over the next $300 \mathrm{~min}$, which is also a two-stage reduction pattern. In the reactors with higher $\mathrm{C} / \mathrm{N}$ ratios $(8$ and 10), $\mathrm{NO}_{3}{ }^{-}-\mathrm{N}$ was almost totally removed from the mixed liquor with a lower residual content $(<0.5 \mathrm{mg} / \mathrm{L})$, indicating the complete denitrification. Additionally, the reduction rate of $\mathrm{NO}_{3}{ }^{-}-\mathrm{N}$ at a $\mathrm{C} / \mathrm{N}$ ratio of 10 was faster than that with a $\mathrm{C} / \mathrm{N}$ ratio of 8 , which could be explained by the higher amount of readily biodegradable organics supplied to accelerate the denitrification processes with the addition of more FSFW.

$\mathrm{NO}_{2}{ }^{-}-\mathrm{N}$ accumulated in the reactors during denitrification (Fig. 1b). Owing to the lack of easily biodegradable organic matter, a very low $\mathrm{NO}_{2}{ }^{-}-\mathrm{N}$ content was detected in the reactors with $\mathrm{C} / \mathrm{N}$ ratios below 6. However, in other reactors, $\mathrm{NO}_{2}{ }^{-} \mathrm{N}$ accumulated and approached the peak value in a short period (approximately 20-30 min). In the reactor with a $\mathrm{C} / \mathrm{N}$ ratio of 6 , the $\mathrm{NO}_{2}{ }^{-}-\mathrm{N}$ concentration increased to $3.2 \mathrm{mg} / \mathrm{L}$ and remained constant until $\mathrm{NO}_{3}{ }^{-}-\mathrm{N}$ was almost eliminated (75 min), then decreased to $0.1 \mathrm{mg} / \mathrm{L}$ after $165 \mathrm{~min} . \mathrm{NO}_{2}{ }^{-} \mathrm{N}$ concentration in the reactors with $\mathrm{C} / \mathrm{N}$ ratios of 8 and 10 exhibited similar tendencies. The accumulation of $\mathrm{NO}_{2}{ }^{-}-\mathrm{N}$ was mainly attributed to the unbalanced electron allocation between nitrate reductase ( $\mathrm{NaR})$ and nitrite reductase (NiR) during denitrification (Cao et al., 2019b; Du et al., 2016; Liu et al., 2016). With the addition of more FSFW to the reactor, the activity of $\mathrm{NaR}$ exceeded that of $\mathrm{NiR}$, or the NiR was provisionally restricted, which resulted in nitrite accumulation. However, a lower nitrite content was observed when the fermented liquid from activated sludge was used (Cao et al., 2019b; Liu et al., 2016), which might be due to the different organic components in the fermented liquid or distinct microbial communities in the sludge (Tang et al., 2018; Liu et al., 2016). After a transitory accumulation, the residual $\mathrm{NO}_{2}{ }^{-}-\mathrm{N}$ in all reactors finally decreased to below $0.1 \mathrm{mg} / \mathrm{L}$, indicating that the FSFW could achieve complete denitrification at a $\mathrm{C} / \mathrm{N}$ ratio above 8 . However, Zhang et al. (2016a) utilized the fermentation liquid from food waste (FLFW) as an external carbon source and achieved complete denitrification at a $\mathrm{C} / \mathrm{N}$ ratio of 6 , which might result from the different organic components of the carbon sources.

The SDNR using the FSFW as carbon source was calculated based on the variations in the contents of nitrogen compounds (Fig. 1c). According to previous studies (Cao et al., 2019a; Sage et al., 2006; Zhang et al., 2016a), organic acids, such as lactic acid and VFAs, are easily utilized by denitrifying bacteria and exhibit a higher SDNR (SDNR $)$, while the macromolecular and particulate organics could be slowly consumed and exhibit a lower nitrate reduction rate $\left(\mathrm{SDNR}_{\mathrm{s}}\right)$. Both 
types of SDNR increased with an increment in the amount of FSFW added, indicating that the denitrification processes were significantly influenced by the concentration of organics in the influent. The easily biodegradable carbon source could be rapidly utilized by denitrifying bacteria and provide more energy for electron transport, thereby promoting their nitrogen removal efficiencies (Sage et al., 2006). Both $\mathrm{SDNR}_{\mathrm{e}}$ and $\mathrm{SDNR}_{\mathrm{s}}$ increased with the $\mathrm{C} / \mathrm{N}$ ratio. $\mathrm{SDNR}_{\mathrm{e}}$ was much higher than $\mathrm{SDNR}_{\mathrm{s}}$, further demonstrating the lower efficacy of slowly biodegradable carbon sources during the denitrification. In the reactor with a C/N ratio of 6 , the $\mathrm{SDNR}_{\mathrm{e}}$ and $\mathrm{SDNR}_{\mathrm{s}}$ were 12.6 and $0.8 \mathrm{mg} / \mathrm{g}$ VSS, respectively, while much higher values were obtained by increasing the $\mathrm{C} / \mathrm{N}$ ratio to 8 (22.4 and $1.4 \mathrm{mg} / \mathrm{g}$-VSS) and 10 (25.3 and $3.0 \mathrm{mg} / \mathrm{g}$-VSS). Obviously, the nitrate in the reactor with a $\mathrm{C} / \mathrm{N}$ ratio of 8 was almost completely removed and much less FSFW was required. Therefore, a $\mathrm{C} / \mathrm{N}$ ratio of 8 was selected as optimal value for future experiments.

Compared with the results in other studies, the SDNR of the FSFW in this work was much higher than that of the hydrolytic $(2.8 \mathrm{mg}-\mathrm{N} / \mathrm{g}$ VSS.h) and acidogenic ( $3.2 \mathrm{mg}-\mathrm{N} / \mathrm{g}$-VSS.h) liquids obtained from activated sludge (Guo et al., 2017), which might be attributed to the different organic components in the carbon sources. Zhang et al. (2016a) utilized the fermentation liquid from food waste (FLFW) and obtained the complete denitrification with a SDNRe of $12.9 \mathrm{mg}-\mathrm{N} / \mathrm{g}$-VSS $\mathrm{h}$ at the $\mathrm{C} / \mathrm{N}$ ratio of 6 , but the separation of soluble organics from the fermented slurry is time-consuming and inapplicable in practical wastewater treatment systems. In addition, compared with the FSFW produced at the thermophilic temperature $(9.2 \mathrm{mg}-\mathrm{N} / \mathrm{g}$-VSS $\mathrm{h}$ ) in our previous study (Tang et al., 2019), the FSFW in this study exhibited a comparable SDNR, and more importantly, the fermentation temperature is lower and more energy could be saved if it could be utilized widely. Based on the analysis above, the FSFW in this study exhibited satisfactory denitrifation performance and could be used as excellent carbon source for enhancing nitrogen removal processes.

\subsubsection{Functions of the organic fractions in FSFW during denitrification}

To explore the relationships between the utilization of organics and denitrification, different fractions of organics in the FSFW were utilized as carbons sources to enhance nitrogen removal at a $\mathrm{C} / \mathrm{N}$ ratio of 8
(Fig. 2). $\mathrm{NO}_{3}{ }^{-}-\mathrm{N}$ in the reactor with soluble fractions sharply decreased from 50 to $1.6 \mathrm{mg} / \mathrm{L}$, while the $\mathrm{NO}_{2}{ }^{-}-\mathrm{N}$ content increased from 0.1 to $9.2 \mathrm{mg} / \mathrm{L}$ during the first $60 \mathrm{~min}$ (Fig. 2a). This was mainly attributed to the presence of low-molecular organic acids in the substrate, such as lactate, acetate, and other VFAs (Tang et al., 2019). Lactate and VFAs can be easily utilized by microorganisms and significantly enhance denitrification (Sage et al., 2006; Tang et al., 2018; Zhang et al., 2016a). As shown in Fig. 2d, the SCOD decreased from 385.1 to $121.3 \mathrm{mg} / \mathrm{L}$, with the LA content sharply decreasing from 222.5 to $65.2 \mathrm{mg}-\mathrm{COD} / \mathrm{L}$, and that of other organics, such as VFAs, declining from 138.4 to approximately $34.9 \mathrm{mg}$-COD/L in the initial $60 \mathrm{~min}$. Protein showed slight decrease during the whole period. The reduction of these micromolecular fermentation products verified the high denitrification rate during this period. After $60 \mathrm{~min}$, the $\mathrm{NO}_{3}{ }^{-}-\mathrm{N}$ content remained constant, but the $\mathrm{NO}_{2}{ }^{-}-\mathrm{N}$ concentration rapidly decreased to $0.25 \mathrm{mg} / \mathrm{L}$ at $150 \mathrm{~min}$. Meanwhile, the SCOD content gradually decreased to approximately $65 \mathrm{mg} / \mathrm{L}$, indicating that the soluble organics in the FSFW could be effectively utilized to achieve complete denitrification.

The reactor with solid fractions exhibited a much lower nitrate reduction rate (Fig. 2b). The $\mathrm{NO}_{3}{ }^{-}-\mathrm{N}$ content slowly decreased from 49.6 to $13.6 \mathrm{mg} / \mathrm{L}$ after $540 \mathrm{~min}$ with a SDNR of $1.52 \mathrm{mg} / \mathrm{g}$-VSS, indicating that, although the solid organics in FSFW could be utilized as carbon sources for nitrogen removal, the SDNR was much lower than that of the soluble fractions. The low denitrification rate was mainly due to the transformation of the solid organics in the FSFW by hydrolytic enzymes before they are utilized by denitrifiers (Tang et al., 2019). However, the hydrolysis rate is lower. Thus, denitrification using solid fractions was much slower than that using soluble fractions. Additionally, the residual $\mathrm{NO}_{3}{ }^{-}-\mathrm{N}$ content $(13.6 \mathrm{mg} / \mathrm{L})$ of this reactor was much higher than that of the other reactors, indicating lower denitrification potential. In this reactor, the initial lactate content was only $5.5 \mathrm{mg}-\mathrm{COD} / \mathrm{L}$, and it could not be detected after $45 \mathrm{~min}$ (Fig. 2e). However, the soluble carbohydrate content first increased from 20 to $51.1 \mathrm{mg}-\mathrm{COD} / \mathrm{L}$, indicating that the hydrolysis rate of carbohydrate was higher than the utilization rate in this stage, which could be due to the hydrolysis of particulate carbohydrates in the anoxic environment. Thereafter, the soluble carbohydrate content decreased and then remained almost
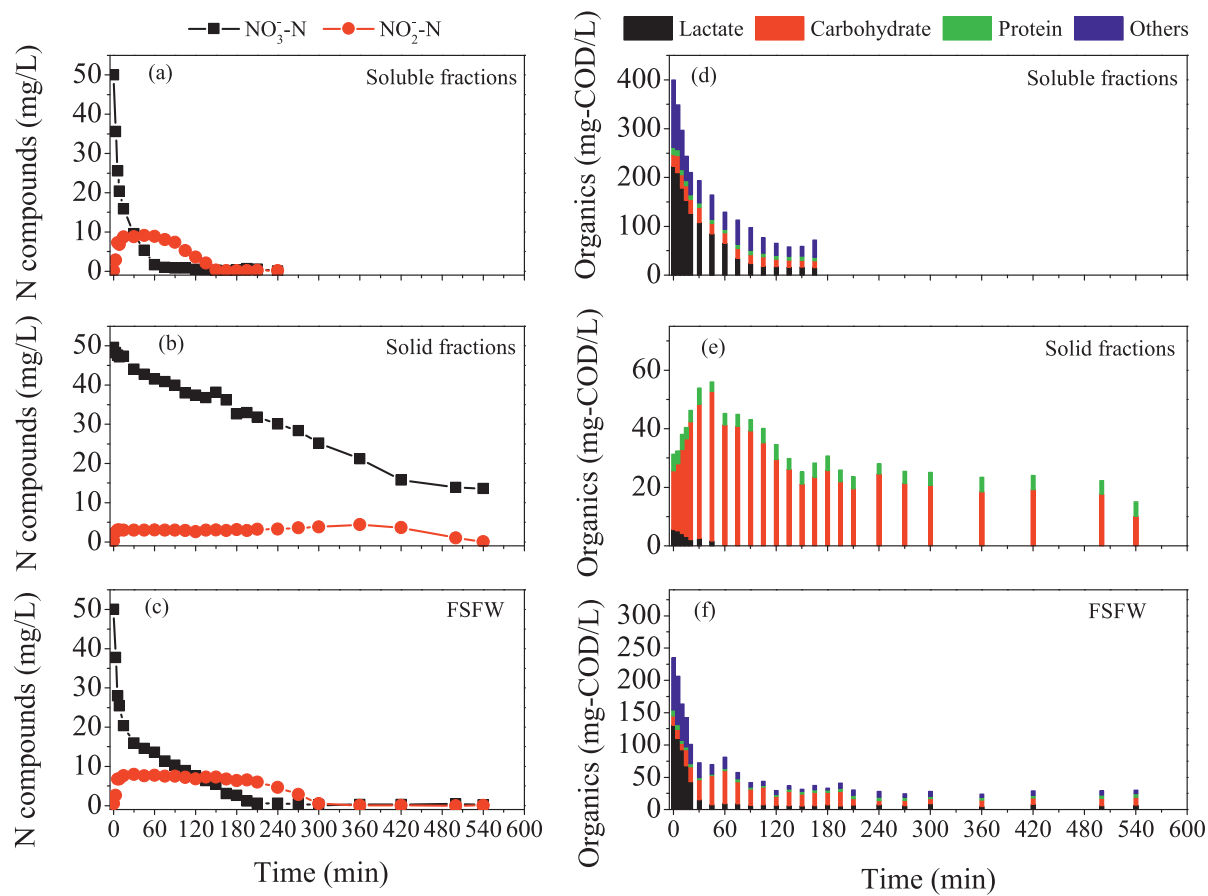

Fig. 2. Nitrogen removal using different organic fractions in the FSFW. Nitrogen compounds content (a,b,c) and organics content (d,e,f). 
constant (approximately $20 \mathrm{mg}$-COD/L), suggesting that the hydrolysis rate was close to the utilization rate and further verifying that solid fractions in the FSFW could be utilized as slow-releasing carbon sources (Kong et al., 2008).

In the reactor with $\mathrm{FSFW}$, the $\mathrm{NO}_{3}{ }^{-}-\mathrm{N}$ content first decreased to approximately $16.0 \mathrm{mg} / \mathrm{L}$ during the initial $30 \mathrm{~min}$, and further reduced to $0.6 \mathrm{mg} / \mathrm{L}$ after $240 \mathrm{~min}$ at a lower rate (Fig. 2c), exhibiting a twostage denitrification profile, as described in the previous section. The reduction of $\mathrm{NO}_{3}{ }^{-}-\mathrm{N}$ could be explained by the variations in the organics of the reactor. Alongside an increase in the soluble carbohydrate content from 14.1 to $51.1 \mathrm{mg}$-COD/L, the lactate was first consumed and its content decreased from 130.7 to $15.2 \mathrm{mg}-\mathrm{COD} / \mathrm{L}$ in the first $30 \mathrm{~min}$ (Fig. 2f), which was similar to the tendencies in the reactors with soluble (Fig. 2d) and solid fractions (Fig. 2e). After the lactate was almost exhausted, the soluble carbohydrate content gradually decreased, which explained the dual denitrification properties of the FSFW in Fig. 2c. During the experiment, the $\mathrm{NO}_{2}{ }^{-}-\mathrm{N}$ content gradually accumulated to $6.5 \mathrm{mg} / \mathrm{L}$, and finally decreased to $0.03 \mathrm{mg} / \mathrm{L}$ (Fig. 2c), which might be due to the intense utilization of easily-biodegradable organics (such as lactate and VFAs) by denitrifying bacteria to transform the $\mathrm{NO}_{3}{ }^{-}-\mathrm{N}$ into $\mathrm{NO}_{2}{ }^{-} \mathrm{N}$, and resulted in the accumulation of nitrite in the reactors (Tang et al., 2018; Liu et al., 2016). Additionally, after the lactate was almost exhausted, carbohydrates and other organics gradually decreased, further demonstrating that the micromolecular organics were consumed before the macromolecular organics (Kong et al., 2008).

The SDNR of soluble fractions $(26.8 \mathrm{mg} / \mathrm{g}$-VSS.h) was the highest of the three types of carbon sources owing to the high proportions of micromolecular organic matter, such as lactate and VFAs. However, the SDNR of the solid fractions was lowest $(1.52 \mathrm{mg} / \mathrm{g}$-VSS $\mathrm{h}$ ), indicating that, although the denitrification was slower, the particulate organics in the FSFW could also be utilized as carbon sources for nitrogen removal. This was because solid organics can be hydrolyzed into soluble organics and utilized by microorganisms (Kong et al., 2008; Tang et al., 2019). The FSFW exhibited a two-stage denitrification pattern, with the first stage $(20.89 \mathrm{mg} / \mathrm{g}$-VSS.h) being almost the same as that of the soluble fractions, and the second stage $(1.52 \mathrm{mg} / \mathrm{g}$-VSS $\mathrm{h})$ being close to that exhibited by solid fractions, further verifying that denitrification of the FSFW involved the synergistic treatment of soluble and solid organics.

From the above analysis, it can be concluded that denitrification was clearly influenced by the concentration and composition of organics in the FSFW. The soluble organics acted as readily biodegradable carbon sources, while the solid fractions were used as slow-releasing organic matter during denitrification. The FSFW exhibited properties of both soluble and solid organics during denitrification, and is a feasible carbon source for removing nitrogen from wastewater.

\subsubsection{Nitrogen removal performance with FSFW during long-term operation}

To explore the nitrogen removal properties of the fermentation products during practical application, the FSFW was supplied as an external carbon source to a SFSBR to treat wastewater with a low C/N ratio $(\mathrm{C} / \mathrm{N}=4-5)$. After adding the FSFW, the COD content in the influent increased to approximately $400 \mathrm{mg} / \mathrm{L}$, resulting in a $\mathrm{C} / \mathrm{N}$ ratio of 8. However, COD content of the effluent stabilized at $15-35 \mathrm{mg} / \mathrm{L}$ throughout the operation, resulting in an average COD removal rate of over $93.5 \%$ (Fig. 3a), demonstrating that the organics in influent could be effectively and completely utilized by the microorganisms in activated sludge, and further indicating that the FSFW could be safely supplied as a carbon source in wastewater treatment systems without deteriorating the effluent quality (Tang et al., 2019).

$\mathrm{NH}_{4}{ }^{+}-\mathrm{N}$ was the dominant nitrogen compound in the influent, and its content fluctuated around $50 \mathrm{mg} / \mathrm{L}$, but it was below $1.0 \mathrm{mg} / \mathrm{L}$ in the effluent, showing a removal efficiency of over $98 \%$ throughout the operation period (Fig. 3b), indicating that the influence of the fermentation products in the FSFW on the activity of ammonia-oxidizing bacteria (AOB) and nitrite-oxidizing bacteria (NOB) during the longterm practical operation was negligible (Tang et al., 2018; Tang et al., 2019). However, the $\mathrm{NO}_{3}{ }^{-}-\mathrm{N}$ content of the effluent was clearly affected by the addition of FSFW. Before adding the FSFW, $\mathrm{NO}_{3}{ }^{-}-\mathrm{N}$ content of the effluent remained above $30 \mathrm{mg} / \mathrm{L}$, with a total nitrogen removal rate of approximately $20-30 \%$, which was mainly due to the low organics content of the influent. After the addition of FSFW, the $\mathrm{NO}_{3}{ }^{-} \mathrm{N}$ content of the effluent gradually decreased to approximately $10 \mathrm{mg} / \mathrm{L}$, indicating that the TN removal efficiency was over $80 \%$, which was mainly due to the addition of FSFW to the influent, providing more carbon sources for denitrifying bacteria and enhancing denitrification (Cao et al., 2019a,b; Tang et al., 2019). Additionally, although the COD content of the influent fluctuated between 300 and $500 \mathrm{mg} / \mathrm{L}$, the nitrate concentration in effluent remained stable, which was likely attributed to the presence of particulate organics in the influent. The particulate organics could slowly release soluble organic matter through hydrolysis and continuously provide carbon sources for denitrification.

Phosphate concentration of the influent was maintained at $6 \mathrm{mg} / \mathrm{L}$, but gradually decreased to below $1 \mathrm{mg} / \mathrm{L}$ in the effluent within the first 30 days due to the addition of FSFW (Fig. 3c). Thereafter, the $\mathrm{PO}_{4}{ }^{3-}-\mathrm{P}$ content fluctuated from 0.2 to $0.9 \mathrm{mg} / \mathrm{L}$, with an average $\mathrm{P}$ removal efficiency of approximately $90.1 \%$, indicating that the addition of FSFW could significantly promote the phosphate removal efficiency. The increment in the $\mathrm{P}$ removal rate may have been caused by two factors: first, the increase in the amount of organics in the influent provided favorable conditions for P release in the anaerobic phase, which facilitated $\mathrm{P}$ absorption under aerobic conditions. Second, the addition of FSFW could have changed the microbial communities and selectively enriched the phosphate-accumulating organisms (PAOs) in the activated sludge (Tang et al., 2019), which will be fully discussed in Section 3.2 .

\subsubsection{Cyclic study}

Cyclic studies were conducted to explore the nitrogen and phosphate removal processes in the SFSBR (Fig. 3). By feeding the reactor with raw wastewater, the $\mathrm{NH}_{4}{ }^{+}-\mathrm{N}$ content approached $16.0 \mathrm{mg} / \mathrm{L}$. Thereafter, the $\mathrm{NH}_{4}{ }^{+}-\mathrm{N}$ content slightly increased to $17.0 \mathrm{mg} / \mathrm{L}$, which was likely due to the hydrolysis of protein or other nitrogenous organic compounds during the anaerobic phase (Fig. 3d). Meanwhile, with the use of organics in the influent as electron donors, the nitrate content gradually decreased from 6.4 to $0.9 \mathrm{mg} / \mathrm{L}$, resulting in a specific denitrification rate (SDNR) of $3.50 \mathrm{mg} \mathrm{NO}{ }_{3}^{-}-\mathrm{N} / \mathrm{g}$-VSS'h (Table 2). Subsequently, with the supply of air during the aerobic phase, the $\mathrm{NH}_{4}{ }^{+}-\mathrm{N}$ was transformed into nitrate by nitrifying bacteria and gradually decreased to $1.15 \mathrm{mg} / \mathrm{L}$ after $105 \mathrm{~min}$, accompanied by an increase in the content of $\mathrm{NO}_{3}{ }^{-}-\mathrm{N}$ from 0.96 to $15.83 \mathrm{mg} / \mathrm{L}$. This translated to a specific nitrification rate (SNR) of $2.48 \mathrm{mg} \mathrm{NH}_{4}{ }^{+}-\mathrm{N} / \mathrm{g}$-VSS.h, which further verified that the activities of $\mathrm{AOB}$ and $\mathrm{NOB}$ were not negatively influenced by the FSFW. The total nitrogen content slightly decreased from 17.3 to $16.0 \mathrm{mg} / \mathrm{L}$ during this period, which translates to a denitrification rate of $0.27 \mathrm{mg} / \mathrm{g}$-VSS $\cdot \mathrm{h}$. This was likely attributable to the existence of simultaneous nitrification and denitrification (SND) processes during this period (Tang et al., 2019).

From 105 to $135 \mathrm{~min}$, the air supply was paused, denitrifying bacteria utilized the residual organics in the reactor for denitrification, and the $\mathrm{NO}_{3}{ }^{-}-\mathrm{N}$ content gradually decreased to $7.6 \mathrm{mg} / \mathrm{L}$. Owing to the degradation of nitrogen organic compounds, the $\mathrm{NH}_{4}{ }^{+}-\mathrm{N}$ content increased from 1.2 to $3.6 \mathrm{mg} / \mathrm{L}$. After $135 \mathrm{~min}$, raw wastewater was fed into the reactor to supply carbon sources and nutrients, and the $\mathrm{NH}_{4}{ }^{+}$$\mathrm{N}$ content increased to $11.8 \mathrm{mg} / \mathrm{L}$, remaining almost constant thereafter. With the provision of a sufficient amount of organics for denitrification, the $\mathrm{NO}_{3}{ }^{-}-\mathrm{N}$ content sharply decreased to $2.3 \mathrm{mg} / \mathrm{L}$ within $15 \mathrm{~min}$, exhibiting a high SDNR (8.2 $\mathrm{mg} \mathrm{N} / \mathrm{g}$-VSS $\cdot \mathrm{h})$, further verifying that organics in the FSFW could be effectively used as carbon sources for nitrogen removal. After another hour (at $195 \mathrm{~min}$ ), the reactor was 

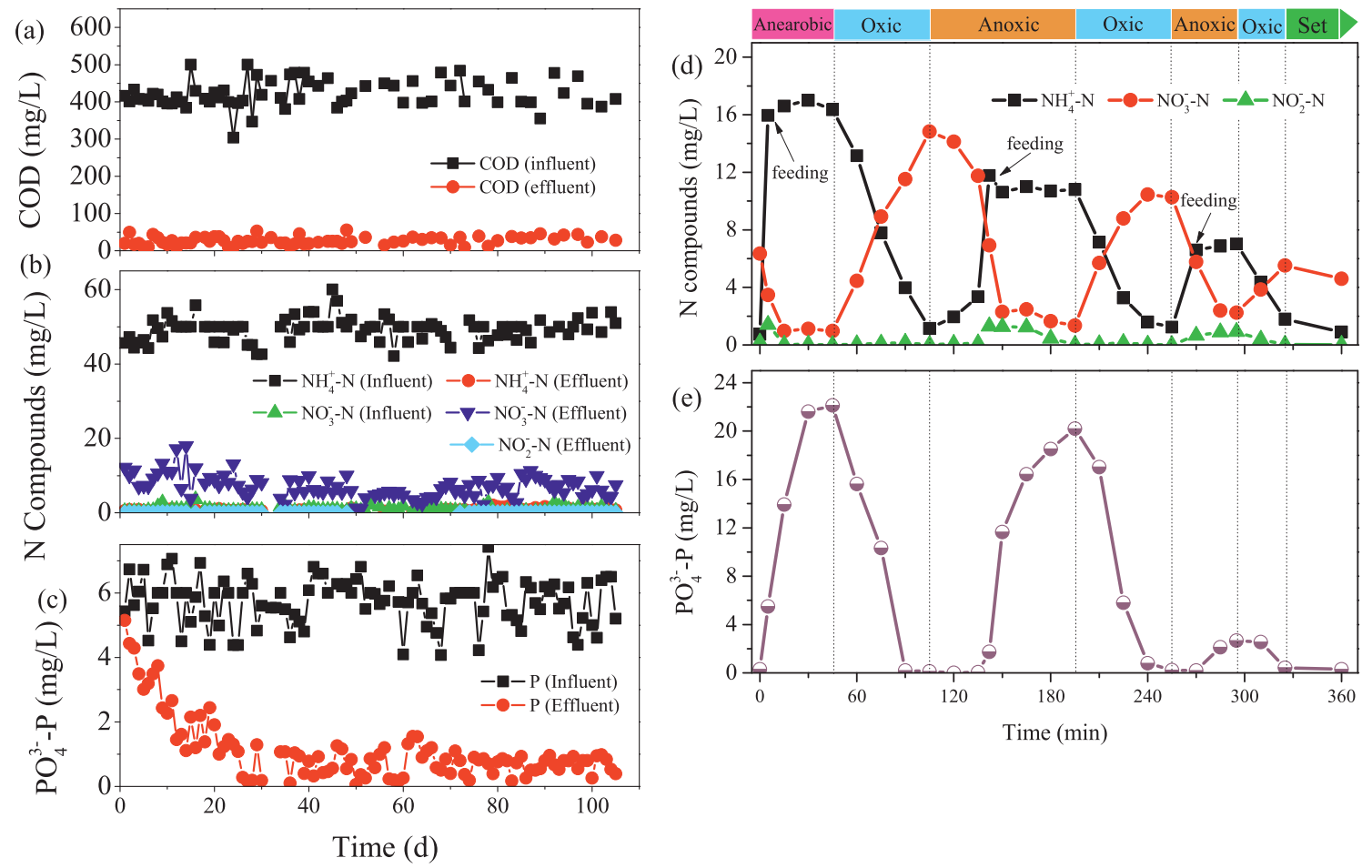

ig. 3. Nutrients removal from SBRs using FSFW as carbon source during the long-term operation (a, b, c) and in one particular cycle at Day 100 (d, e).

aerated, and the $\mathrm{NH}_{4}{ }^{+}-\mathrm{N}$ content gradually decreased to $1.3 \mathrm{mg} / \mathrm{L}$ while the $\mathrm{NO}_{3}{ }^{-}-\mathrm{N}$ content increased to $10.5 \mathrm{mg} / \mathrm{L}$. Nitrification and denitrification rates of $2.66 \mathrm{mg} \mathrm{NH}{ }_{4}^{+}-\mathrm{N} / \mathrm{g}$-VSS.h and $0.30 \mathrm{mg} \mathrm{N} / \mathrm{g}$ VSS $h$ were achieved, respectively. Within the next $40 \mathrm{~min}$, with the organics from the influent as carbon sources, the $\mathrm{NO}_{3}{ }^{-}-\mathrm{N}$ content gradually decreased to $2.4 \mathrm{mg} / \mathrm{L}$, resulting in a denitrification rate of $3.74 \mathrm{mg} \mathrm{N} / \mathrm{g}$-VSS.h. During the last oxic phase (295-325 min), the $\mathrm{NH}_{4}{ }^{+}-\mathrm{N}$ content decreased to $1.8 \mathrm{mg} / \mathrm{L}$ while that of $\mathrm{NO}_{3}{ }^{-}-\mathrm{N}$ increased to $5.5 \mathrm{mg} / \mathrm{L}$, indicating that the $\mathrm{NH}_{4}{ }^{+}-\mathrm{N}$ was completely transformed by the nitrifiers into $\mathrm{NO}_{3}{ }^{-}-\mathrm{N}$ with a high SNR $\left(2.48 \mathrm{mg} \mathrm{NH}_{4}{ }^{+}-\mathrm{N} / \mathrm{g}\right.$ VSS.h).

The variations in the $\mathrm{PO}_{4}{ }^{3-}-\mathrm{P}$ content of the SFSBR were analyzed. In the anaerobic phase, with the supply of sufficient easily-biodegradable organic carbon sources, the P concentration increased from 0.3 to $22.1 \mathrm{mg} / \mathrm{L}$ (Fig. 3e), and the reactor showed a high phosphate release rate of $4.1 \mathrm{mg} \mathrm{P} / \mathrm{g}$-VSS h (Table 2). As phosphate accumulated under aerobic conditions, the $\mathrm{PO}_{4}{ }^{3-}$-P content sharply decreased to $0.2 \mathrm{mg} / \mathrm{L}$ within $45 \mathrm{~min}$, demonstrating that the $\mathrm{P}$ accumulation rate of the activated sludge was very high $(4.76 \mathrm{mg} / \mathrm{g}$-VSS $\mathrm{h})$. In the anoxic phase, with the feeding of organics from the influent, the $\mathrm{PO}_{4}{ }^{3-}-\mathrm{P}$ content gradually increased to $20.2 \mathrm{mg} / \mathrm{L}$ after the $\mathrm{NO}_{3}{ }^{-}{ }^{-} \mathrm{N}$ was fully removed (150 min), further indicating that the organics in the FSFW could be easily utilized by phosphate-accumulating microorganisms (PAOs) to achieve satisfactory phosphate release. Owing to the sufficient $\mathrm{P}$ release, the concentration of $\mathrm{PO}_{4}{ }^{3-}-\mathrm{P}$ gradually decreased to $0.8 \mathrm{mg} / \mathrm{L}$ from 195 to $240 \mathrm{~min}$, indicating a $\mathrm{P}$ accumulation rate of $5.60 \mathrm{mg} / \mathrm{g}$ VSS.h. After the third feeding, as less organics were supplied, the $P$ release rate was lower $(0.87 \mathrm{mg} / \mathrm{g}$-VSS $\mathrm{h})$ and the $\mathrm{PO}_{4}{ }^{3-}$-P content of the mixed liquor slightly increased to $2.68 \mathrm{mg} / \mathrm{L}$ from 255 to $295 \mathrm{~min}$. However, the phosphate concentration sharply decreased to $0.43 \mathrm{mg} / \mathrm{L}$ with aeration, which ensured a low content $(0.3 \mathrm{mg} / \mathrm{L})$ in the effluent. Unlike the results achieved using FSFW from thermophilic fermentation in a previous study (Tang et al., 2019), denitrifying phosphate removal was not observed here, which could be due to the distinct organic components in the fermented slurry or different microbial communities in the activated sludge.

\subsection{Characteristics of the activated sludge}

\subsubsection{Variations of EPS}

The variations in the EPS (SEPS and BEPS) during operation were investigated to explore the effect of FSFW on the activated sludge properties. The total EPS content increased from 39.5 to $59.6 \mathrm{mg} / \mathrm{g}$-VSS after 30 days with the addition of FSFW, in which BEPS was the main component, and sharply climbed to $45.3 \mathrm{mg} / \mathrm{g}$-VSS (Table 3). Thereafter, the EPS gradually accumulated, and its content increased to $77.4 \mathrm{mg} / \mathrm{g}$-VSS, with the BEPS content reaching $59.0 \mathrm{mg} / \mathrm{g}$-VSS after 100 days. In both SEPS and BEPS, the polysaccharide content varied slightly, while proteins gradually accumulated with the addition of FSFW, which was similar to the results of our previous studies (Tang

Table 2

The calculated nitrogen and phosphate removal rate during the cyclic study.

\begin{tabular}{lllllll}
\hline & \multicolumn{2}{l}{ Unit: $\mathrm{mg} / \mathrm{g}$-VSS.h } \\
\cline { 2 - 7 } & Anaerobic (0-45 min) & Aerobic (45-105 min) & Anoxic (105-195 min) & Aerobic (195-255 min) & Anoxic (255-295 min) & Aerobic (295-325 min) \\
\hline Nitrification rate & - & 2.48 & - & 2.66 & - & 2.48 \\
Denitrification rate & 3.50 & 0.27 & 8.18 & 0.30 & 3.74 & -35 \\
P release rate & 4.06 & - & 4.52 & - & - & 1.87 \\
P accumulation rate & - & 4.76 & - & 5.60 & - & 1.07 \\
\hline
\end{tabular}

Note: The nitrogen and phosphate removal rate was calculated with the data in the cyclic study; - represented no detection. 
Table 3

Variations of EPS during the long-term operation of SBR.

\begin{tabular}{|c|c|c|c|c|c|c|}
\hline \multirow{3}{*}{ Sample } & \multicolumn{6}{|l|}{ Unit: mg/g-VSS } \\
\hline & \multicolumn{3}{|l|}{ SEPS } & \multicolumn{3}{|l|}{ BEPS } \\
\hline & Polysaccharide & Protein & Total & Polysaccharide & Protein & Total \\
\hline Raw sludge & $1.6 \pm 0.2$ & $3.2 \pm 1.1$ & $4.8 \pm 1.4$ & $7.1 \pm 2.4$ & $27.5 \pm 6.2$ & $34.6 \pm 8.9$ \\
\hline 30 day & $0.5 \pm 0.3$ & $13.8 \pm 1.5$ & $14.3 \pm 2.0$ & $4.9 \pm 1.8$ & $40.3 \pm 5.4$ & $45.3 \pm 7.2$ \\
\hline 100 day & $1.0 \pm 0.5$ & $17.7 \pm 3.3$ & $18.6 \pm 3.6$ & $9.4 \pm 1.5$ & $49.5 \pm 7.9$ & $59.0 \pm 9.2$ \\
\hline
\end{tabular}

et al., 2017; Tang et al., 2019). The increase in the content of EPS might be attributed to the changes in the microbial communities of the sludge or the shift in bacterial metabolism after the addition of FSFW. Additionally, the proteins and carbohydrates in the FSFW also contributed to the accumulation of EPS in the activated sludge (Tang et al., 2017). EPS are essential to sludge granulation and could be utilized as carbon sources (Zhang et al., 2016b), and an increase in the EPS content provided excellent conditions for the removal of pollutants (Long et al., 2017).

3D-EEM was conducted to further compare the differences in EPS before and after the addition of FSFW (Fig. 4). There were three clear peaks for the SEPS, while two peaks were observed for the BEPS, among which peaks A and B indicated aromatic protein and tryptophan protein-like substances, respectively, while peak $C$ indicated the presence of humic acid-like substances (Chen et al., 2003). Peaks A and B were detected in all samples, indicating that the addition of FSFW did not significantly change the EPS components. However, peaks A and B shifted towards red wavelengths for the SEPS after the addition of FSFW, indicating that the FSFW affected bacterial metabolism or changed the microbial communities. Additionally, the intensity of both peaks in the samples after the addition of FSFW was higher than that before, which is consistent with the increment in the content of EPS (Table 3).

\subsubsection{Sludge particle size, dewaterability, and oxygen uptake rate}

The particle size of the activated sludge flocs increased with the addition of fermentation products (Supplementary Information). The initial mean size of sludge flocs was approximately $110.1 \mu \mathrm{m}$ (0 Day), and it increased to $130.6 \mu \mathrm{m}$ with the addition of FSFW after 30 days (Table 4). Larger particles (mean size of $209.8 \mu \mathrm{m}$ ) were found after 100 days. The increase in the size of sludge flocs was mainly attributed to the particulate organics in the fermented slurry, which behaved as a core for bacteria attachment and enrichment (Tang et al., 2019). A larger sludge floc size was beneficial for separating the activated sludge from the treated water and ensuring the production of high-quality effluent. Moreover, the larger sludge flocs could provide suitable microenvironments for the SND process, resulting in the decrease in the total nitrogen during the aerobic phases in Fig. 3, which is consistent with the results of our previous study (Tang et al., 2019). The SVI decreased from 101.9 to $73.5 \mathrm{~mL} / \mathrm{g}$-VSS after the addition of FSFW, indicating that the activated sludge had good settleability. In terms of the CST, the dewaterability of the activated sludge was improved by adding FSFW, which might have resulted in the increase in sludge size and decrease in the content of SEPS (Ye et al., 2012). It has been reported that the components of EPS (such as loosely bonded EPS) could influence bioflocculation and sludge-water separation (Li and Yang, 2007), which will be investigated in the future. Additionally, the SOUR, particularly that of heterotrophic microorganisms, increased from 24.1 to
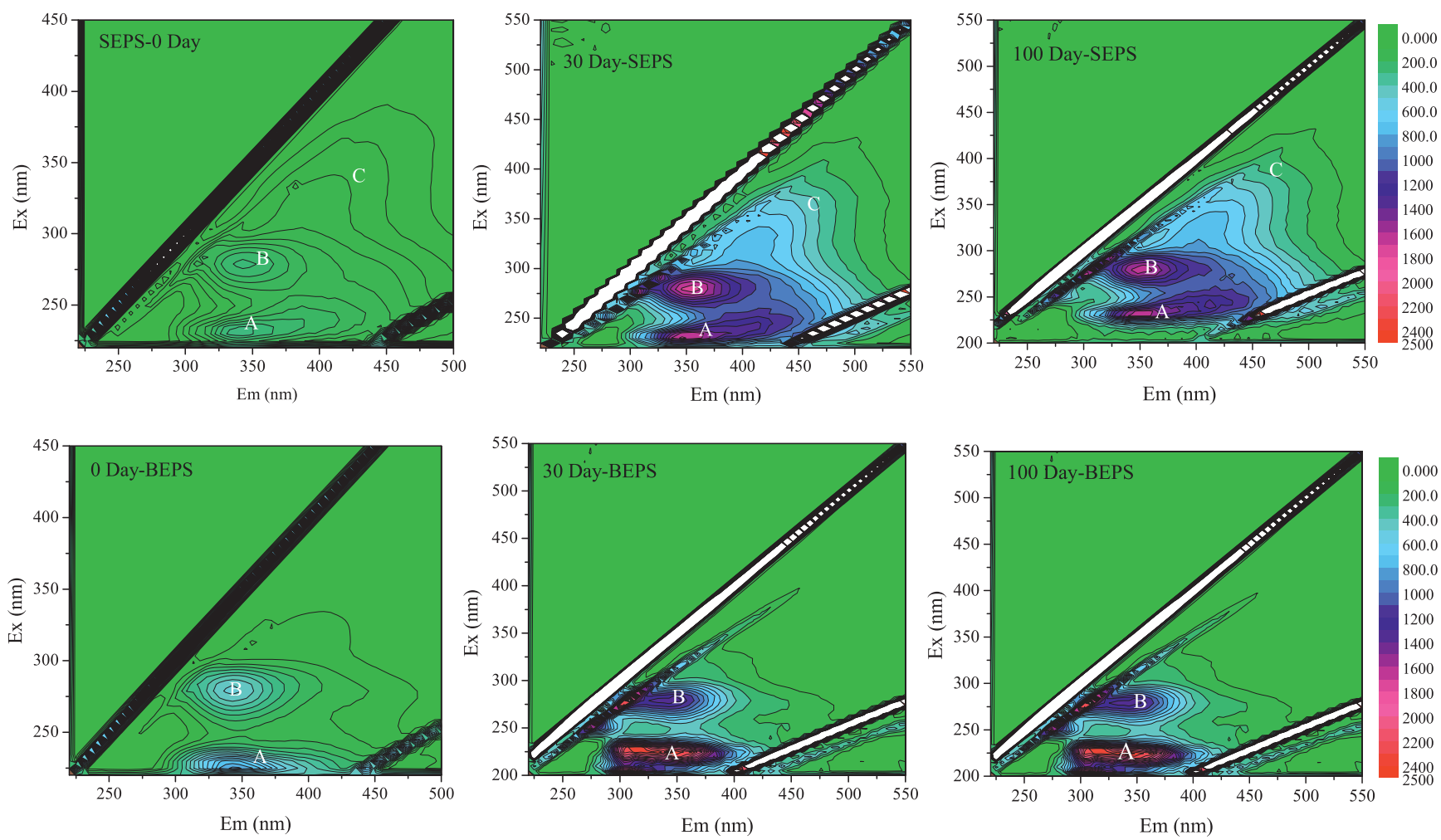

Fig. 4. 3D-EEM of SEPS and BEPS in the SBR during the operation. 
Table 4

Variations of sludge properties in the SBR with the FSFW.

\begin{tabular}{|c|c|c|c|c|c|c|}
\hline Time (days) & MLSS (g/L) & MLVSS/MLSS & SVI (mL/g-VSS) & Mean particle size $(\mu \mathrm{m})$ & CST (s.L/g-VSS) & SOUR $\mathrm{mg} \mathrm{O} \mathrm{O}_{2} / \mathrm{g}$-VSS \\
\hline 0 & $3.1 \pm 0.4$ & $0.80 \pm 0.2$ & $101.9 \pm 17.3$ & 110.1 & $2.5 \pm 0.7$ & $24.1 \pm 2.2$ \\
\hline 30 & $3.5 \pm 0.3$ & $0.83 \pm 0.1$ & $78.6 \pm 15.9$ & 130.6 & $2.3 \pm 0.3$ & $23.4 \pm 3.7$ \\
\hline 100 & $4.3 \pm 0.5$ & $0.85 \pm 0.2$ & $73.5 \pm 20.1$ & 209.8 & $2.2 \pm 0.5$ & $26.2 \pm 3.5$ \\
\hline
\end{tabular}

$26.2 \mathrm{mg} \mathrm{O} \mathrm{O}_{2} / \mathrm{g}$-VSS, which was mainly attributed to the sufficient amount of organic matter from the addition of FSFW, and ensured the high pollutant removal efficiencies.

\subsubsection{Microbial communities in the activated sludge}

The substrate in influent could change the microbial community structures of the activated sludge, which would in turn affect the pollutant removal performance and sludge properties (Tang et al., 2019). Therefore, the microbial communities of the activated sludge before $(0$ Day) and after (100 Day) the addition of FSFW were investigated by high-throughput sequencing to further explore the effect of FSFW addition on wastewater treatment.

Proteobacteria and Bacteroidetes were the dominant phyla of both sludge samples (Fig. 5a), which is consistent with our previous study
(Tang et al., 2019). Before the addition of FSFW (0 Day), the relative abundance of Proteobacteria was $61.2 \%$, which was much higher than that after the addition of FSFW (47.2\%). However, the abundance of Bacteroidetes increased from $16.2 \%$ to $30.4 \%$ after 100 days, indicating that the microbial communities changed after the addition of FSFW. Bacteroidetes can digest complicated organics (Rivière et al., 2009), and the increase in the Bacteroidetes abundance was favorable for degrading the macromolecular and particulate organics in the FSFW and improving the nutrient removal efficiencies. Additionally, the abundance of Chloroflexi, a phylum responsible for the degradation of complicated substrates (Miura et al., 2007), slightly increased from $7.5 \%$ to $8.5 \%$ after the addition of FSFW. Moreover, Verrucomicrobia $(0.7 \%$ to $3.6 \%)$ and Planctomycetes $(1.6 \%$ to $4.9 \%)$ accumulated in the sludge cultured with FSFW, which provided favorable conditions for the
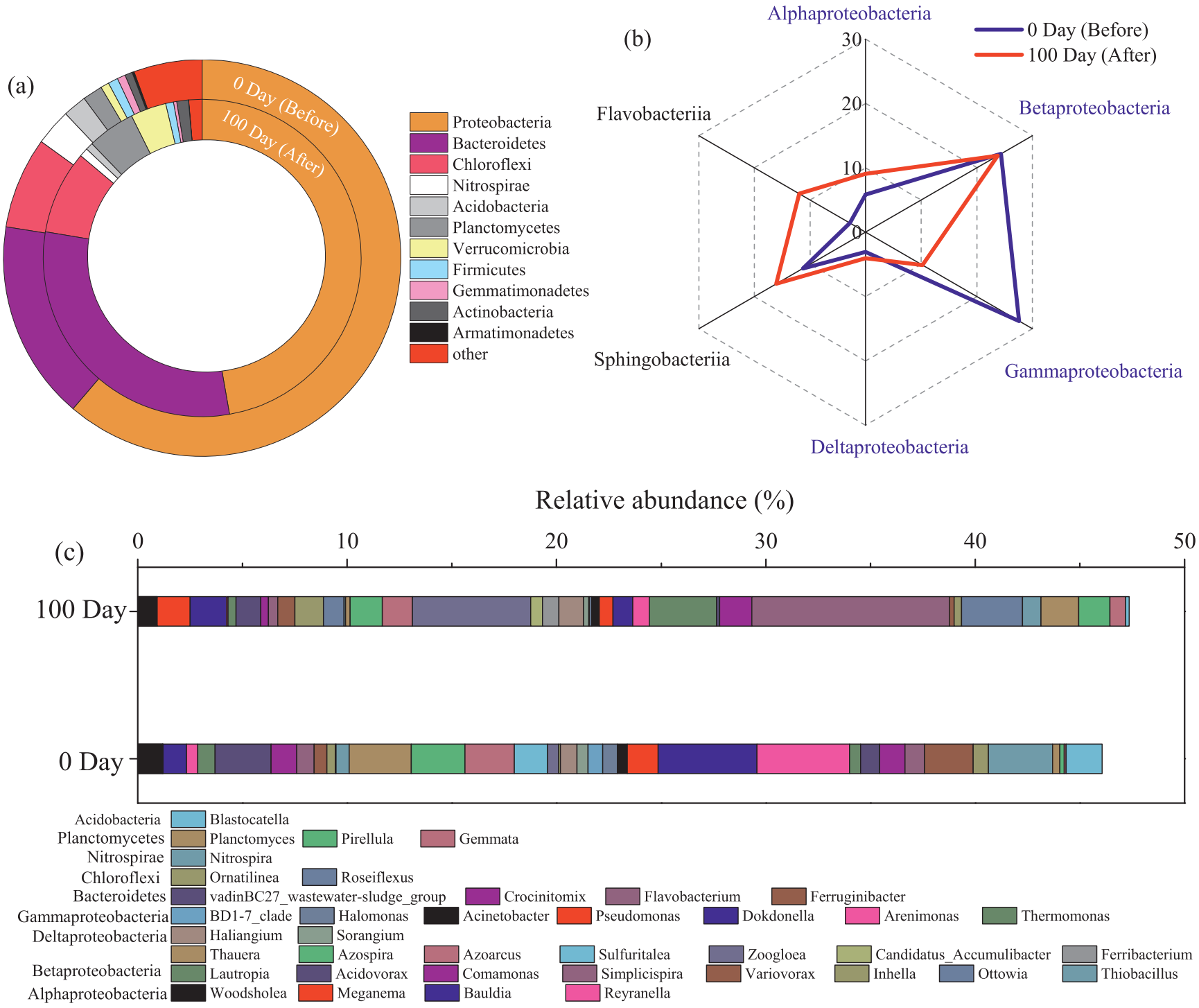

Fig. 5. Variations of microbial communities in the activated sludge before and after adding the FSFW. (a) phyla level, (b) the dominant classes and (c) the first 40 genera. 
degradation of complicated organic matter (Cardman et al., 2014). Actinobacteria could enhance the hydrolysis of carbon sources and nutrients removal, and their abundance increased from $0.6 \%$ to $1.2 \%$ (Kinh et al., 2017; Kong et al., 2008). Thus, the increases in the abundances of these phyla promoted the digestion of complex organics (such as particulate and macromolecular organics) in the fermentation products, which were favorable for promoting nutrients removal.

At the class level, the abundances of Alphaproteobacteria, Betaproteobacteria, Gammaproteobacteria, and Deltaproteobacteria changed after adding the FSFW (Fig. 5b). The relative abundance of Betaproteobacteria remained almost unchanged during operation and that of Gammaproteobacteria significantly decreased from $27.6 \%$ to $10.2 \%$, while Alphaproteobacteria $(5.8 \%$ to $9.0 \%)$ and Deltaproteobacteria $(3.1 \%$ to $4.1 \%)$ slightly accumulated during operation, promoting the degradation of biopolymeric organic matter (Shangguan et al., 2015). The decrease in the abundance of Gammaproteobacteria might be due to the negative effects of some of the organics in FSFW on this class, which will be further investigated in the future. The relative abundances of both Sphingobacteriia and Flavobacteriia increased after the addition of FSFW, which further explained the high COD and nutrient removal efficiencies of the reactor (Shangguan et al., 2015).

By further classifying the OTUs at the genus level, more differences between these two samples could be observed (Fig. 5c). Meganema, a genus of Alphaproteobacteria, has the functions of EPS production, denitrification and polyhydroxyalkanoate (PHA) storage (Kragelund et al., 2005; Szabó et al., 2017). The enrichment of this genus (from $0.02 \%$ to $1.57 \%$ ) promoted the nitrogen removal rate. Of the Betaproteobacteria, Zoogloea, a genus of Rhodocyclaceae, is responsible for denitrification (Chen et al., 2019), and its abundance increased from $0.5 \%$ to $5.6 \%$. Additionally, Zoogloea is associated with EPS excretion (Chen et al., 2019). The enrichment of this genus explained the accumulation of EPS after the addition of FSFW (Table 4). Although Meganema and Zoogloea may result in poor sludge settling when they are predominant in activated sludge, small populations of these two genera are often found in activated sludge, and they are very important for sludge granulation (Szabó et al., 2017). The abundances of Dokdonella and Arenimonas, which are genera of Gammaproteobacteria, decreased during operation, but Thermomonas with a relative abundance of $3.2 \%$ was largely detected in the reactor. Thermomonas is a contributor to heterotrophic denitrification (Xing et al., 2018), and the accumulation of this genus further verified the high nitrogen removal efficiency of the reactor. Flavobacterium, a genus of Sphingobacteriia, has a satisfactory denitrification ability (Chang et al., 2019), and the enrichment of this genus from $0.9 \%$ to $9.4 \%$ also explained the higher nitrogen removal rate. Additionally, Roseiflexus was not detected in the inoculate sludge, but its relative abundance was $2.9 \%$ after cultivation with the FSFW, which further enhanced the removal of nutrients and organics. The selective enrichment of these genera in the reactor after adding FSFW provided satisfactory conditions for digesting the complex organics in the FSFW and promoting nitrogen and phosphate removal. Moreover, the detection of phosphate-accumulating bacteria (Candidatus Accumulibacter, with a relative abundance of $0.6 \%$ ) in the sludge after the addition of FSFW further explained the high phosphate removal efficiency (Kim et al., 2010; Zeng et al., 2016). Based on the above analysis, it can be concluded that the addition of FSFW to the reactor caused certain microbiota in the activated sludge to accumulate, promoting substrate degradation and nutrients removal.

\section{Conclusions}

The organic acids in FSFW acted as easily biodegradable carbon sources, while particulate and macromolecular organics were slowly biodegraded during denitrification. The $\mathrm{C} / \mathrm{N}$ ratios significantly influenced nitrogen removal performance, and a $\mathrm{C} / \mathrm{N}$ ratio of 8 achieved complete denitrification in batch tests and clearly improved the nitrogen and phosphate removal efficiencies during the long-term operation of a SBR. After adding the FSFW, EPS obviously accumulated, sludge floc size significantly increased, and certain microbial communities were enriched. Thus, the FSFW produced by acidogenic fermentation at mesophilic temperature is an excellent intermediary between FW disposal and wastewater treatment.

\section{Acknowledgments}

This work was financially supported by grants from the National Program of Water Pollution Control in China (Grant no. 2013ZX07310001), the Natural Science Foundation of China (Grant no. 51778522 and 51508450), the Program for Innovative Research Team in Shanxi Province (Grant no. 2013KCT-13), the Start-up Fund of Chengdu University (Grant no. 2081917045) and the Solid-state Fermentation Resource Utilization Key Laboratory of Sichuan Province (no. 2018GTJ008).

No conflict of interest exits in the submission of this manuscript, and manuscript is approved by all authors for publication.

\section{Appendix A. Supplementary data}

Supplementary data to this article can be found online at https:// doi.org/10.1016/j.biortech.2019.122218.

\section{References}

APHA, 2012. Standard Methods for the Examination of Water and Wastewater, 21st ed. American Public Health Association. Washington, DC

Braguglia, C.M., Gallipoli, A., Gianico, A., Pagliaccia, P., 2018. Anaerobic bioconversion of food waste into energy: A critical review. Bioresource Technol. 248, 37-56.

Cao, S., Sun, F., Lu, D., Zhou, Y., 2019a. Characterization of the refractory dissolve d organic matters (rDOM) in sludge alkaline fermentation liquid driven de nitrification: Effect of HRT on their fate and transformation. Water Res. 159, 135-144.

Cao, S., Qian, T., Zhou, Y., 2019b. New insights on the sludge fermentation liquid driven denitrification: Evaluation of the system performance and effluent organic matter (EfOM). Bioresource Technol. 289, 121621.

Capson-Tojo, G., Rouez, M., Crest, M., Steyer, J.P., Delgenès, J.P., Escudié, R., 2016. Food waste valorization via anaerobic processes: a review. Rev. Environ. Sci. Bio. 15 (3), 499-547.

Cardman, Z., Arnosti, C., Durbin, A., Ziervogel, K., Cox, C., Steen, A.D., Teske, A., 2014. Verrucomicrobia are candidates for polysaccharide-degrading bacterioplankton in an Arctic fjord of Svalbard. Appl. Environ. Microb. 80 (12), 3749-3756.

Chang, M., Wang, Y., Pan, Y., Zhang, K., Lyu, L., Wang, M., Zhu, T., 2019. Nitrogen removal from wastewater via simultaneous nitrification and denitrification using a biological folded non-aerated filter. Bioresource Technol. 289, 121696.

Chen, C., Ming, J., Yoza, B.A., Liang, J., Li, Q.X., Guo, H., Liu, Z., Deng, J., Wang, Q., 2019. Characterization of aerobic granular sludge used for the treatment of petroleum wastewater. Bioresource Technol. 271, 353-359.

Chen, W., Westerhoff, P., Leenheer, J.A., Booksh, K., 2003. Fluorescence excitation - emission matrix regional integration to quantify spectra for dissolved organic matter. Environ. Sci. Technol. 37 (24), 5701-5710.

Drewnowski, J., Makinia, J., 2014. The role of biodegradable particulate and colloidal organic compounds in biological nutrient removal activated sludge systems. Int. J. Environ. Sci. Technol. 11 (7), 1973-1988.

Du, R., Peng, Y., Cao, S., Li, B., Wang, S., Niu, M., 2016. Mechanisms and microbial structure of partial denitrification with high nitrite accumulation. Appl. Microbiol. Biot. 100, 2011-2021.

Frølund, B., Palmgren, R., Keiding, K., Nielsen, P.H., 1996. Extraction of extracellular polymers from activated sludge using a cation exchange resin. Water Res. 30 (8), 1749-1758.

Guo, Y., Guo, L., Sun, M., Zhao, Y., Gao, M., She, Z., 2017. Effects of hydraulic retention time (HRT) on denitrification using waste activated sludge thermal hydrolysis liquid and acidogenic liquid as carbon sources. Bioresource Technol. 224, 147-156.

Hu, Y., Wang, X.C., Zhang, Y., Li, Y., Chen, H., Jin, P., 2013. Characteristics of an A ${ }^{2} O-$ MBR system for reclaimed water production under constant flux at low TMP. J. Membr. Sci. 431, 156-162.

Jiang, Y., Dennehy, C., Lawlor, P.G., Hu, Z., McCabe, M., Cormican, P., Zhan, X., Gardiner, G.E., 2018. Inhibition of volatile fatty acids on methane production kinetics during dry co-digestion of food waste and pig manure. Waste Manage. 79, 302-311.

Kim, E., Shin, S.G., Mah, J., Tongco, J.V., Hwang, S., 2017. Use of food waste-recycling wastewater as an alternative carbon source for denitrification process: a full-scale study. Bioresource Technol. 245, 1016-1021.

Kim, J., Kim, J., Lee, C., 2019. Anaerobic co-digestion of food waste, human feces, and toilet paper: Methane potential and synergistic effect. Fuel 248, 189-195.

Kim, J.M., Lee, H.J., Kim, S.Y., Song, J.J., Park, W., Jeon, C.O., 2010. Analysis of the FineScale Population Structure of "Candidatus Accumulibacter phosphatis" in Enhanced Biological Phosphorus Removal Sludge, Using Fluorescence In Situ Hybridization and Flow Cytometric Sorting. Appl. Environ. Microb. 76 (12), 3825. 
Kinh, C.T., Suenaga, T., Hori, T., Riya, S., Hosomi, M., Smets, B.F., Terada, A., 2017. Counter-diffusion biofilms have lower $\mathrm{N}_{2} \mathrm{O}$ emissions than co-diffusion biofilms during simultaneous nitrification and denitrification: Insights from depth-profile analysis. Water Res. 124, 363-371.

Kong, Y., Xia, Y., Nielsen, P.H., 2008. Activity and identity of fermenting microorganisms in full-scale biological nutrient removing wastewater treatment plants. Environ. Microbiol. 10 (8), 2008-2019.

Kragelund, C., Nielsen, J.L., Thomsen, T.R., Nielsen, P.H., 2005. Ecophysiology of the filamentous Alphaproteobacterium Meganema perideroedes in activated sludge. FEMS Microbiol. Ecol. 54 (1), 111-122.

Kwan, T.H., Hu, Y., Lin, C.S.K., 2018. Techno-economic analysis of a food waste valorisation process for lactic acid, lactide and poly(lactic acid) production. J. Clean. Prod. $181,72-87$.

Li, X.Y., Yang, S.F., 2007. Influence of loosely bound extracellular polymeric substances (EPS) on the flocculation, sedimentation and dewaterability of activated sludge. 2007. Water Res. 41, 1022-1030.

Liu, F., Tian, Y., Ding, Y., Li, Z., 2016. The use of fermentation liquid of wastewater primary sedimentation sludge as supplemental carbon source for denitrification based on enhanced anaerobic fermentation. Bioresour. Technol. 219, 6-13.

Liu, H., Han, P., Liu, H., Zhou, G., Fu, B., Zheng, Z., 2018. Full-scale production of VFAs from sewage sludge by anaerobic alkaline fermentation to improve biological nutrients removal in domestic wastewater. Bioresour. Technol. 260, 105-114.

Long, X., Tang, R., Fang, Z., Xie, C., Li, Y., Xian, G., 2017. The roles of loosely-bound and tightly-bound extracellular polymer substances in enhanced biological phosphorus removal. Chemosphere 189, 679-688.

Lowry, O.H., Rosebrough, N.J., Farr, A.L., Randall, R.J., 1951. Protein measurement with the Folin phenol reagent. J. Biol. Chem. 193 (1), 265-275.

Luo, W., Phan, H.V., Xie, M., Hai, F.I., Price, W.E., Elimelech, M., Nghiem, L.D., 2017. Osmotic versus conventional membrane bioreactors integrated with reverse osmosis for water reuse: Biological stability, membrane fouling, and contaminant removal. Water Res. 109, 122-134.

Mehariya, S., Patel, A.K., Obulisamy, P.K., Punniyakotti, E., Wong, J.W.C., 2018. Codigestion of food waste and sewage sludge for methane production: Current status and perspective. Bioresour. Technol. 265, 519-531.

Miura, Y., Watanabe, Y., Okabe, S., 2007. Significance of Chloroflexi in performance of submerged membrane bioreactors (MBR) treating municipal wastewater. Environ. Sci. Technol. 41 (22), 7787-7794.

Rivière, D., Desvignes, V., Pelletier, E., Chaussonnerie, S., Guermazi, S., Weissenbach, J., Li, T., Camacho, P., Sghir, A., 2009. Towards the definition of a core of microorganisms involved in anaerobic digestion of sludge. Isme J. 3 (6), 700-714.

Sage, M., Daufin, G., Gésan-Guiziou, G., 2006. Denitrification potential and rates of complex carbon source from dairy effluents in activated sludge system. Water Res. 40 (14), 2747-2755.

Shangguan, H., Liu, J., Zhu, Y., Tong, Z., Wu, Y., 2015. Start-up of a spiral periphyton bioreactor (SPR) for removal of COD and the characteristics of the associated microbial community. Bioresour. Technol. 193, 456-462.

Surmacz-Gorska, J., Gernaey, K., Demuynck, C., Vanrolleghem, P., Verstraete, W., 1996. Nitrification monitoring in activated sludge by oxygen uptake rate (OUR) measurements. Water Res. 30 (5), 1228-1236.

Szabó, E., Liébana, R., Hermansson, M., Modin, O., Persson, F., Wilén, B.M., 2017. Microbial population dynamics and ecosystem functions of anoxic/aerobic granular sludge in sequencing batch reactors operated at different organic loading rates. Front. Microbiol. 8, 770.

Tang, J., Wang, X., Hu, Y., Zhang, Y., Li, Y., 2016. Lactic acid fermentation from food waste with indigenous microbiota: Effects of $\mathrm{pH}$, temperature and high OLR. Waste Manage. 52, 278-285.

Tang, J., Wang, X.C., Hu, Y., Ngo, H.H., Li, Y., Zhang, Y., 2017. Applying fermentation liquid of food waste as carbon source to a pilot-scale anoxic/oxic-membrane bioreactor for enhancing nitrogen removal: Microbial communities and membrane fouling behaviour. Bioresour. Technol. 236, 164-173.

Tang, J., Wang, X.C., Hu, Y., Pu, Y., Huang, J., Hao Ngo, H., Zeng, Y., Li, Y., 2018. Nitrogen removal enhancement using lactic acid fermentation products from food waste as external carbon sources: Performance and microbial communities. Bioresour. Technol. 256, 259-268.

Tang, J., Wang, X.C., Hu, Y., Pu, Y., Huang, J., Ngo, H.H., Zeng, Y., Li, Y., 2019. Nutrients removal performance and sludge properties using anaerobic fermentation slurry from food waste as an external carbon source for wastewater treatment. Bioresour. Technol. 271, 125-135.

Xing, W., Li, J., Li, P., Wang, C., Cao, Y., Li, D., Yang, Y., Zhou, J., Zuo, J., 2018. Effects of residual organics in municipal wastewater on hydrogenotrophic denitrifying microbial communities. J. Environ. Sci. 65, 262-270.

Ye, F., Liu, X., Li, Y., 2012. Effects of potassium ferrate on extracellular polymeric substances (EPS) and physicochemical properties of excess activated sludge. J. Hazard. Mater. 199-200, 158-163.

Zeng, W., Zhang, J., Wang, A., Peng, Y., 2016. Denitrifying phosphorus removal from municipal wastewater and dynamics of "Candidatus Accumulibacter" and denitrifying bacteria based on genes of ppk1, narG, nirS and nirK. Bioresour. Technol. 207, 322-331.

Zhang, C., Su, H., Baeyens, J., Tan, T., 2014. Reviewing the anaerobic digestion of food waste for biogas production. Renew. Sust. Energ. Rev. 38, 383-392.

Zhang, Y., Wang, X.C., Cheng, Z., Li, Y., Tang, J., 2016a. Effect of fermentation liquid from food waste as a carbon source for enhancing denitrification in wastewater treatment. Chemosphere 144, 689-696.

Zhang, Y., Wang, X.C., Cheng, Z., Li, Y., Tang, J., 2016b. Effects of additional fermented food wastes on nitrogen removal enhancement and sludge characteristics in a sequential batch reactor for wastewater treatment. Environ. Sci. Pollut. Res. 23 (13), 12890-12899.

Zhou, M., Yan, B., Wong, J.W.C., Zhang, Y., 2018. Enhanced volatile fatty acids production from anaerobic fermentation of food waste: A mini-review focusing on acidogenic metabolic pathways. Bioresource Technol. 248, 68-78. 